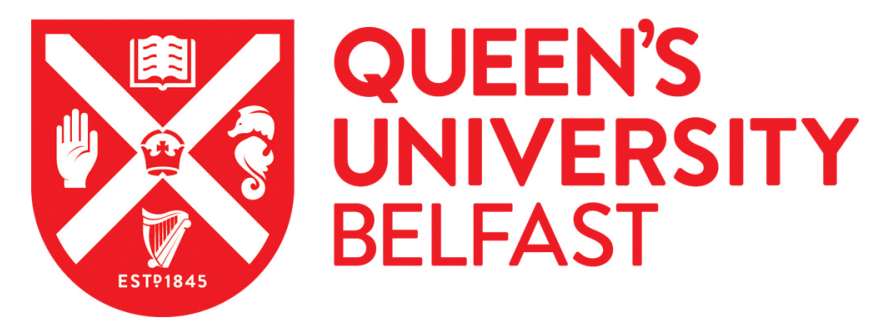

\title{
Nutritional Properties of Ready-to-Eat Pasta Salads: Effect of Processing and Storage Conditions
}

Delgado-Pando, G., Stratakos, A. CH., \& Koidis, A. (2016). Nutritional Properties of Ready-to-Eat Pasta Salads: Effect of Processing and Storage Conditions. Journal of Food Processing and Preservation. https://doi.org/10.1111/jfpp.13124

Published in:

Journal of Food Processing and Preservation

Document Version:

Peer reviewed version

Queen's University Belfast - Research Portal:

Link to publication record in Queen's University Belfast Research Portal

Publisher rights

(c) 2016 Wiley \& Sons Ltd.

This is the peer reviewed version of the following article: Delgado-Pando, G., Stratakos, A. Ch. and Koidis, A. (2016), Nutritional Properties of Ready-to-Eat Pasta Salads: Effect of Processing and Storage Conditions. Journal of Food Processing and Preservation. which has been published in final form at http://onlinelibrary.wiley.com/wol1/doi/10.1111/jfpp.13124/abstract This article may be used for non-commercial purposes in accordance with Wiley Terms and Conditions for Self-Archiving.

\section{General rights}

Copyright for the publications made accessible via the Queen's University Belfast Research Portal is retained by the author(s) and / or other copyright owners and it is a condition of accessing these publications that users recognise and abide by the legal requirements associated with these rights.

Take down policy

The Research Portal is Queen's institutional repository that provides access to Queen's research output. Every effort has been made to ensure that content in the Research Portal does not infringe any person's rights, or applicable UK laws. If you discover content in the Research Portal that you believe breaches copyright or violates any law, please contact openaccess@qub.ac.uk. 
1 Nutritional properties of ready-to-eat pasta salads. Effect of processing and storage conditions

2 Gonzalo Delgado-Pando ${ }^{\dagger}$, Alexandros Ch. Stratakos $^{\dagger}$, Anastasios Koidis $^{\dagger *}$

$3{ }^{\dagger}$ Queen's University Belfast, Institute for Global Food Security, Belfast, Northern Ireland, UK.

4 * Corresponding author

5 Dr Anastasios (Tassos) Koidis, Institute for Global Food Security

6 Queen's University Belfast, 18-30 Malone Road

7 Belfast, BT9 5BN, Northern Ireland, UK

$8 \quad$ Tel: +442890975569

9 email: t.koidis@qub.ac.uk

10 Short version of title: Nutritional properties of RTE salads 
1 ABSTRACT: Nutritional properties of ready-to-eat meals can vary greatly during storage due to the

2 complexity of their food matrix. The nutritional properties of two types of ready-to-eat pasta salads

3 differing in the processing of one of their ingredients (bell pepper) were evaluated during 12 days

4 of storage at 4 and $12{ }^{\circ} \mathrm{C}$. Salads with cooked (C) or uncooked (UC) red bell pepper were analyzed

5 for proximate composition, dietary fiber content, lipid profile, ascorbic acid degradation kinetics

6 and in vitro digestion of starch; rapid digestible starch and predicted glycemic index were also

7 calculated. Results showed that vegetable processing significantly affected the ascorbic acid

8 degradation, starch hydrolysis, as well as the fat and energy content of the salads. Nutritional

9 properties of commercially available ready-to-eat pasta salads may significantly differ between

10 manufacturers depending on the processing applied, storage temperature and time after

11 production, and thus this should be seriously considered when evaluating their health implications.

12 Keywords: ready-to-eat, nutritional quality, ascorbic acid, predicted glycemic index, storage

13 PRACTICAL APPLICATIONS: Despite the convenience and ease of preparation of ready-to-eat meals, consumers should be aware that health benefits claimed by some ingredients included in these products might be lessened by the storage conditions (time and temperature), type of processing and interaction with other constituents of the product. This work provides food manufacturers with an in depth insight on how these factors can affect the nutritional properties of their products and lead to foods that can retain the full potential of their nutritional

20 foods is encouraged. 
2 Over recent decades, ready-to-eat (RTE) foods have undergone a huge expansion in the food

3 industry and household consumption. These types of food products have several attributes that

4 make them very popular, such as convenience, time saving and suitability when eating alone. Their

5 varied composition of ingredients hinders their nutritional assessment as a homogeneous group,

6 which has resulted in a lack of studies about nutritional composition and impact of these foods on

7 the daily recommended nutrient intake (Fajardo-Martín, 2013, Ahlgren et al., 2004). Pasta products

8 (such as pasta) are consumed worldwide, are rich in complex carbohydrates (i.e. starch) and have

9 good sensory attributes. They are traditionally manufactured with durum wheat flour and can be

10 used in several preparations to make important nutritional principles (Antognelli, 1980, Rodríguez

11 De Marco et al., 2014). The inclusion of fresh or slightly processed vegetables in ready-to-eat meals,

12 such as in chilled pasta salads, is the market response for the consumers' demands of fresh, healthy

13 and convenient foods. However, the shelf life and nutritional properties of these meals would vary

14 greatly due to the presence of several ingredients in the formulation and the processing taking

15 prior to their use, something that is often over sighted when evaluating their health properties. In

16 order to increase the shelf life of these RTE salads, the use of novel technologies (aqueous ozone,

17 cold plasma, among others) and natural preservatives are being studied (Boffa et al., 2016, Lui et

18 al., 2016, Stratakos \& Koidis, 2015).

19 Because of the complex nature of RTE foods, several operational challenges are involved. During

20 production and storage, labile compounds, present as major and minor constituents of the food,

21 can degrade and lose their biological activity. To prevent or reduce this degradation a better

22 understanding of the factors affecting the stability during processing and storage is needed. It is

23 important to evaluate the degradation of ascorbic acid (AA) during processing and storage because 
it is more sensitive than other micronutrients. In fact, it is the most labile vitamin (including fat soluble and water soluble vitamins) especially at higher moisture content and temperature (Labuza, 1984). Therefore, it can be assumed that if AA retention is reportedly high, other micronutrients will have similar or higher retention rates after processing and storage. The degradation rate of AA depends on several factors, such as: temperature, light, oxygen, $\mathrm{pH}$, water activity, metal catalysts (especially copper and iron) and enzymes (Özkan et al., 2004). For quality assurance and bioactive compounds retention, several parameters should be controlled during the manufacturing and storage of RTE vegetable-containing foods. Degradation kinetics of AA dependent on temperature and storage time have been extensively studied in a wide range of fruits and vegetables (Cruz et al., 2008, Uddin et al., 2002, Polydera et al., 2003, Zheng and Lu, 2011, Özkan et al., 2004). The effect of storage time on the AA content in sweet pepper (Capsicum annuum L.) has been evaluated under different conditions (Barbagallo et al., 2012, Tonelli et al., 1981), and AA degradation kinetics for this product were focused only on the dehydration process with no storage involved (RufiánHenares et al., 2013). To date, the complete picture on the minimization of losses of AA in chilled stored meals coupled with a detailed kinetic study that would provide a better understanding of the underlying mechanisms has not been yet performed. matrix; kinetics of starch digestion are influenced by the presence of proteins, lipids (and lipid profile), dietary fiber, antinutrients, enzyme inhibitors and several interactions that could occur amongst them. Food processing, storage time and temperature play a role in how these

21 interactions occur, modifying enzymatic rates, starch physical forms, protein networks formation 22 and starch-lipid complexation (Marze, 2013, Wursch, 1989, Björck et al., 1994). The glycemic response can be measured by the Glycemic Index (GI), defined as the postpandrial blood glucose 
response after a test meal compared with equi-carbohydrate portion of reference food (generally glucose or white bread) (Jenkins et al., 1981). Several authors have observed a good correlation between the in vivo and in vitro determinations, being the latter much less costly and time consuming (Singh et al., 2010). In vitro determination of GI have been thoroughly studied in several single foods (flour, potatoes, pasta, bread, etc) (Bustos et al., 2011, Zhou et al., 2013, Nayak et al., 2014, Goñi et al., 1997) however only a few studies have been performed with more complex foods and/or during storage (Sayago-Ayerdi et al., 2005, Tovar et al., 2003, Rosin et al., 2002). Recent studies have associated the consumption of low GI foods with weight loss, improvement of the blood lipid profile and prevention of metabolic diseases (Rizkalla, 2014, Thomas et al., 2007). The utility of GI in relation with health prevention and management is discussed in the highest level amongst experts. They acknowledge the importance of $\mathrm{Gl}$ as a valid and reproducible method for classifying carbohydrate rich foods with regards to postpandrial glycemia in health, and they affirmed that diets low in GI were relevant to the prevention and management of diabetes, coronary heart disease and probably obesity (Augustin et al., 2015). Given the high prevalence of all these diseases and the high consumption of RTE foods, more studies and scientific evidence should be provided about $\mathrm{Gl}$ in this type of meals.

In this study, the aim was to investigate the effect of processing, storage time and temperature in a range of nutritional properties of a RTE food product which is both complex and widely consumed.

The nutritional composition (including fatty acid profile and dietary fiber), the ascorbic acid content, and the predicted GI were evaluated with regards to their behavior during cold and abuse

21 temperature storage in an attempt to build a better picture of the nutritive status of such complex 22 foods in domestic or industrial storage conditions. 
3 Ingredients for the preparation of the ready-to-eat (RTE) pasta salads included: wheat pasta (fusilli),

4 RTE chicken breast, grated mozzarella, gouda cheese, red bell pepper, extra virgin olive oil, salt,

5 lemon, and black pepper. They were all purchased from a local wholesaler. HPLC grade

6 orthophosphoric acid, chloroform, metaphosporic acid (MPA), ethylenediaminetetraacetate

7 disodium salt (EDTA), ACS grade ascorbic acid (AA) (>99\% pure), sodium phosphate buffer (PBS),

8 3,5-dinitrosalicylic acid, hydrochloric acid $(\mathrm{HCl})$, and sodium hydroxide $(\mathrm{NaOH})$ were purchased

9 from Sigma Aldrich (Seelze, Germany). AA extraction buffer was 5\% MPA and 1 mM EDTA in mili Q

10 water. The following enzymes were also purchased from the same company: Amyloglucosidase

11 from Aspergillus niger $\geq 300 \mathrm{U} / \mathrm{ml}$, pepsine from porcine gastric mucosa $\geq 250 \mathrm{U} / \mathrm{mg}$ and $\alpha$-amylase

12 from porcine pancreas Type IV-B $\geq 10 \mathrm{U} / \mathrm{mg}$.

\section{Design and preparation of ready to eat pasta salads}

15 Two different formulations of the RTE salads were prepared with the only difference being the treatment of the red bell pepper: cooked (C) or uncooked (UC). The formulation is shown in Table 1 and is based on a commercial recipe already in the market. The preparation of the ingredients and the salads were as follow: fusilli (pasta) was cooked following the instructions recommended by the producer; red bell pepper was cut into small pieces and then either washed under running water for $10 \mathrm{~min}$ (uncooked) or cooked in boiling water for $3 \mathrm{~min}$ and cooled in ice cold water for $5 \mathrm{~min}$

21 (cooked); lemon juice was prepared the same day with fresh lemons; gouda cheese was grated with

22 a kitchen grinder; RTE meat and mozzarella cheese were used directly from the package. For each

23 batch, all the ingredients were mixed separately and then the exact weight (Table 1) was added to 
the cooked and cooled pasta in the following order: bell pepper, chicken, Gouda cheese, mozzarella

cheese, lemon juice, pepper, salt and olive oil. The salads were carefully mixed before packaging.

The salads were portioned in pouches ( $200.0 \mathrm{~g}$ each, 6 pouches per batch) and were packed under modified atmosphere packaging (MAP) with a gas mixture of $60 \% \mathrm{~N}_{2}$ and $40 \% \mathrm{CO}_{2}$. Gas composition was checked with a headspace gas analyzer (Gaspace advance GS3/P, Systech Instruments, IL, USA). The salads were stored at $4{ }^{\circ} \mathrm{C}$ and $12{ }^{\circ} \mathrm{C}$ for 12 days, and their nutritional content was assessed right after preparation (day 0), and the ascorbic acid content and in vitro digestion of starch was performed also at day 4,8 and 12 of the storage period. This length was selected according to the shelf life of this specific RTE product as per manufacturer guideline. The experiment was performed twice with three different batches of raw materials per type of salad. Salads were homogenized before any determination and $5 \mathrm{~g}$ were taken for each analysis unless stated otherwise.

\section{Nutritional composition and fatty acid profile}

Moisture, protein and dietary fiber content of the salads were obtained following the standard AOAC methods in triplicate . Fat content was evaluated in triplicate according to the method proposed by Folch et al. (1957) and reviewed by Christie and Han (2012). The fatty acid composition of the pasta salads was determined (duplicates per type of salad) twice: immediately after preparation and after 12 days of storage. The extracted fat was derivatized to Fatty Acid Methyl Esters (FAME) following a base-catalyzed transesterification methodology (Christie and Han, 2012). The FAMES were analyzed using gas chromatography-mass spectrometry (GC-MS) detection (GCMS Agilent 7890A/5975C), resolved on a CP-Sil 88 column (100 m x $0.5 \mathrm{~mm} 0.2 \mu \mathrm{m})$ under the following conditions: split injection; injection port temperature $250^{\circ} \mathrm{C}$; helium flow $1 \mathrm{ml} / \mathrm{min}$; initial oven temperature $100^{\circ} \mathrm{C}$ for $0 \mathrm{~min}$, then $4^{\circ} \mathrm{C} / \mathrm{min}$ rise to $220^{\circ} \mathrm{C}$ for $5 \mathrm{~min}$, then $4^{\circ} \mathrm{C} / \mathrm{min}$ to $240^{\circ} \mathrm{C}$ for 8 
min. Data were collected by using Agilent MSD Chemstation software (CA, USA). The relative peak areas (analyte/total FAME area, \%) were used for relative quantification of FAME. Fatty acids were identified by comparison with a known standard FAME mixture (Supelco, Iltech Associated, Deerfield, IL, USA). Based on the FAME results, the atherogenic index (AI) and thrombogenic index (TI) were computed according to Ulbricht and Southgate (1991):

$$
A I=\frac{C 12: 0+4 * C 14: 0+C 16: 0}{\sum M U F A+\sum P U F A}
$$

$$
T I=\frac{C 14: 0+C 16: 0+C 18: 0}{0.5 * \sum M U F A+0.5 * \sum P U F A(n 6)+3 * \sum P U F A(n 3)+\frac{P U F A(n 3)}{P U F A(n 6)}}
$$

\section{Ascorbic acid determination}

11 Ascorbic acid content of salads and red bell pepper was extracted and analyzed based on the methodology proposed by Tarrago-Trani et al. (2012) with some modifications. RTE salads (200 g) were homogenized in a kitchen blender for $2 \mathrm{~min}$. From this homogenate, $2.5 \mathrm{~g}$ of representative sample was mixed and vortexed with $20 \mathrm{ml}$ of chloroform and capped under nitrogen flow. After centrifugation the supernatant was discarded and the remaining excess of solvent was evaporated under a stream of nitrogen. This defatting step was used to facilitate the filtration in the following extraction. The defatted salad sample, were homogenized with $12 \mathrm{ml}$ of extraction buffer using an homogenizer (Ultraturrax T25 Basic, IKA, Staufen, Germany) for 3 min and were capped under nitrogen. They were sonicated for $5 \mathrm{~min}$ and centrifuged at $4500 \mathrm{rpm}$ for $15 \mathrm{~min}$ at $10^{\circ} \mathrm{C}$; supernatant was collected. A second extraction was performed following the same process above, supernatants were combined and vacuum filtered. The filtrate was adjusted to $25 \mathrm{ml}$ (with 
extraction buffer) in a volumetric flask, capped under nitrogen and stored at $-20{ }^{\circ} \mathrm{C}$. Extracted samples were analyzed, in duplicate, within 2 weeks. AA analysis was carried out in a Reversed Phase HPLC system (Waters 2695, Massachusetts, USA) with photodiode array detector (model 2996). The HPLC column used was a Luna $5 \mu \mathrm{m}$ C18(2) reversed phase column (Phenomenex, UK). The mobile phase was aqueous ortophosphoric acid $(0.02 \%)$ at $\mathrm{pH}=2.35$. An aliquot was filtered through $0.45 \mu \mathrm{m}$ membrane filter into a $2 \mathrm{ml}$ amber HPLC vial and capped under nitrogen ready to be analyzed in the HPLC. Exactly $20 \mu$ l were injected and eluted under isocratic conditions at 0.6 $\mathrm{ml} / \mathrm{min}$ flow rate. The AA peak was detected after around $7 \mathrm{~min}$ at a wavelength of $244 \mathrm{~nm}$. AA standards (diluted in extraction buffer) were run several times during the analysis for quality control purposes. A calibration curve was made with the injection of increasing concentrations of AA standards (from $0.2-30 \mathrm{mg} / \mathrm{ml}$ ). The linearity range was assessed by means of the correlation coefficient $\left(R^{2}\right)$ of the linear regression analysis of the calibration curve. The analysis was performed 13 in triplicate.

\section{Total Starch and analysis of reducing sugar content}

The total starch content of the RTE salads was assessed using the method of Goñi et al. (1997) and aliquots were taken to analyze their reducing sugar content. The analysis of reducing sugar content was performed using a colorimetric method (Gonçalves et al., 2010). A standard curve, using maltose, was prepared. The maltose was converted into starch by multiplying by 0.9 .

\section{In vitro digestion of starch and predicted glycemic index}

The in vitro digestion of starch was performed according to the multi enzymatic methodology proposed by Bustos et al. (2011). Briefly, triplicate samples (4 g) were incubated first with pepsine and then with alpha amylase. Every $30 \mathrm{~min}$ for $3 \mathrm{~h}$, aliquots of $1 \mathrm{ml}$ from each tube were withdrawn 
1 for analysis of reducing sugar content using aforementioned colorimetric method. The rate of

2 starch digestion was expressed as the percentage of total starch hydrolyzed at every $30 \mathrm{~min}$. The

3 curves have been reported (Goñi et al., 1997) to follow a first order equation:

$$
C=C_{\infty}\left(1-e^{-k t}\right)
$$

5 Where: $C$ is the concentration of starch hydrolyzed at time $t, C_{\infty}$ is the equilibrium concentration, $k$

6 is the kinetic constant and $t$ is the chosen time. A curve of the total starch hydrolysis vs. time was

7 plotted for each sample (salad type and storage temperature) and the areas under the curve (AUC)

8 were calculated. The Hydrolysis Index was obtained by dividing the AUC by the corresponding area

9 of a reference food (white bread), expressed as percentage (Granfeldt et al., 1992). The predicted

10 Glycemic Index (pGI) was calculated from hydrolysis values at 90 min using the empirical formula

11 proposed by Goñi et al. (1997) $\mathrm{pGI}=39.21+0.803 \times \mathrm{H}_{90}$.

\section{Statistical Analysis}

14 Data were analyzed using IBM SPSS Statistics version 20 (IBM Corp., Somers, NY, USA), t-student test was performed to assess differences in composition among the different type of RTE salads.

16 For the evaluation of the effect of storage and temperature a two-way ANOVA was performed. The

17 least squares differences (LSD) post hoc test was used to identify significant differences between 18 the temperature and storage time. For estimating the AA degradation kinetics and starch digestion 19 kinetics parameters, curve fit was utilized. The level of significance was set at $p<0.05$ unless stated 20 otherwise.

RESULTS AND DISCUSSION

23 Nutritional composition and fatty acid profile 
The processing of red bell pepper was the only difference in the RTE salads formulation, and this ingredient accounts for $15 \%$ of the total ingredient composition (Table 1). No significant

3

4

differences were found in the moisture, protein and dietary fiber of both type of salads, with values around $65 \mathrm{~g} / 100 \mathrm{~g}, 11 \mathrm{~g} / 100 \mathrm{~g}$ and $1 \mathrm{~g} / 100 \mathrm{~g}$, respectively. However, the fat content of the UC salads was significantly higher than of the $C$ salads, $10.75 \pm 0.51$ vs. $9.28 \pm 0.81 \mathrm{~g} / 100 \mathrm{~g}$. Based on the formulation, around $30 \%$ of this fat comes from the cheeses, $10 \%$ from the meat and $60 \%$ from the olive oil. This small difference in fat content could be attributed to the insufficient product uniformity between different batches. The UC salads had higher energy content $(193.28 \mathrm{kcal} / 100 \mathrm{~g})$ than the $\mathrm{C}$ salads (186.24 kcal/100 g). As expected, there was no statistical difference between fatty acid composition of $C$ and UC salads; the mean of both salads was used instead. Two thirds of the fatty acid composition in both type of salads ( $C$ and UC) were monounsaturated fatty acids (MUFA), where oleic acid (C18:1 n9) was the main one (Table 2, day 0). Two different indexes of fat quality were also assessed: atherogenic index (AI) thrombogenic index (TI). Both indexes were similar to those reported by Kamei et al. (2002) in take-out lunches and fast foods. Unsaturated fatty acids are the ones that can suffer different chemical oxidative reactions resulting in fatty acid degradation, the higher the number of double bonds the higher the rate of the oxidation reaction (Morelló et al., 2004). Despite the absence of oxygen in the package (MAP), the salads stored at $12{ }^{\circ} \mathrm{C}$ during 12 days showed changes in their fatty acid composition when compared with the salads right after preparation (Table 2). These changes were probably due to the highly unsaturated lipid profile (mostly MUFA), the increase of residual oxygen and the interaction among the different enzymes and antioxidants during the storage at abuse temperature. There was a significant decrease of oleic and linoleic fatty acid and an increase of the saturated fatty acids caproic (C6:0) and caprylic (C8:0). Hence, the overall MUFA content significantly decreased after the storage time but no statistically significant increase was observed in the SFA content. As stated before, olive oil 
was the main fat-contributing ingredient of the RTE salads; the storage time, and container type affect the degradation of fatty acids in this type of oil during long storage (Méndez and Falqué,

3 2007). Despite the decrease in unsaturated fatty acids and the increase in SFA content, the increase

$4 \quad$ in the $\mathrm{Al}$ and $\mathrm{TI}$ was not significant.

5

\section{Effect of processing on the ascorbic acid content}

According to different nutritional databases, from all the ingredients of the RTE salads (Table 1), the red bell pepper is the main contributor to the AA content of the RTE pasta salad with a percentage between 99.2-99.5\% (USDA, Food Standard Agency). Hence, the processing of this vegetable was studied before being used in the final formulation. Results showed that processing significantly affected the AA content of the vegetable in all treatments. The initial AA content of cut red bell pepper was $97.39 \pm 3.92 \mathrm{mg} / 100 \mathrm{~g}$. This value is in agreement with those reported in nutritional databases for different varieties, between $76 \mathrm{mg}$ and $243 \mathrm{mg} / 100 \mathrm{~g}$ (USDA, Food Standard Agency). After 10 min of washing under running water, $21.50 \pm 8.12 \%$ of the initial AA content was lost $(p<0.05)$. When the red bell pepper was boiled for $3 \mathrm{~min}$ and cooled down under running water, the AA content was significantly lower. Only $45.70 \%$ of the initial AA was retained after the cooking and cooling process. These results were similar to those found by Castro et al. (2008) in sweet red bell pepper, where around 55\% AA retention was observed after 2.5 min of blanching at $98^{\circ} \mathrm{C}$. Higher AA losses were found in Jalapeño cultivars (75\% loss) and after processing a tropical leafy vegetable, $60-90 \%$ after 15 min cooking and 50\% after the washing process (Oteng-Gyang and Mbachu, 1987, Howard and Hernandez-Brenes, 1998).

There is a significant difference $(p<0.05)$ between the AA content in the salad with cooked bell pepper $(7.05 \pm 0.41 \mathrm{~g} / 100 \mathrm{~g})$ and the one with uncooked bell pepper $(12.56 \pm 1.52 \mathrm{~g} / 100 \mathrm{~g})$. It is evident that processing of the red bell pepper had a substantial impact in the final AA 
concentration of the salad, resulting in $43 \%$ decrease of total AA content. According to the initial formulation and the AA content of the red bell pepper after processing, the vegetable accounts for $81-103 \%$ of the AA total content in the salad, confirming what the nutritional databases had already shown. The UC salads could theoretically be labeled as a source of Vitamin C as they contain more than $15 \%$ of the nutritional reference value (NRV) for this compound ( $\mathrm{NRV}=80 \mathrm{mg}$ vit $\mathrm{C} / 100 \mathrm{~g}$ ).

\section{Effect of storage and temperature on the ascorbic acid content. Degradation kinetics. AA} retention yields were calculated for the RTE pasta salads stored at $4{ }^{\circ} \mathrm{C}$ and $12{ }^{\circ} \mathrm{C}$ under MAP conditions. The effect of temperature during storage in the AA retention was evaluated by means of a two-way ANOVA for each type of salad. Storage time had significant effect in the AA retention of the salads (Table 3). Except for the salads stored under MAP at $4^{\circ} \mathrm{C}$, a decrease in the AA content during storage was observed in the RTE pasta salads. Temperature effect was significant for both types of salads ( $C$ and $U C$ ); the higher the temperature, the lower the AA retention (Table 3 ). An increase in the storage temperature was found to decrease the AA retention in different fruits and vegetables, with acidic fruits being the most stable against temperature changes (Lee and Kader, 2000).

From the experimental data of AA retention as function of storage temperature and time, we estimated a model in order to explain the substantial loss in the nutritional quality of the RTE pasta salads previously observed. C salads stored at $4{ }^{\circ} \mathrm{C}$ did not show AA degradation and were removed from the analysis. Table 4 shows the rate constants $(k)$ and the coefficient of determination $\left(R^{2}\right)$ for both types of salads at each studied temperature $\left(4^{\circ} \mathrm{C}\right.$ and $\left.12^{\circ} \mathrm{C}\right)$. For $\mathrm{C}$ salads, the zero reaction modeling fitted better than the first order according to the coefficient of determination and the plot trend. However, for the UC salads, the first order reaction model provided the best fit for AA 
retention during storage time. The coefficients of determination were higher for the $\mathrm{C}$ salads compared with the UC salads. The rate constants indicated that the AA was more stable in the salads with uncooked bell pepper than in the salads where the pepper had been boiled, in accordance with the results so far. Zero order reactions were also found for AA degradation kinetics

5 in various fruit juices stored at $20^{\circ} \mathrm{C}, 30^{\circ} \mathrm{C}$ and $40^{\circ} \mathrm{C}$ during 12 days (Özkan et al., 2004). In zeroorder reactions the rate appears to be independent of the concentration due to the large excess of reactant during the observation period (Van Boekel, 2008). However, the first order kinetic best explains the AA degradation at different temperature ranges and/or during longer storage periods as seen in fruit juices and dried guava cases (Uddin et al., 2002, Polydera et al., 2003, Zheng and Lu, 2011). Differences in the type of kinetic can be addressed to the food matrix, the storage time and

11 the range of temperatures studied.

12 According to Table 4, the AA retention during storage was temperature dependent for the UC salads. The Arrhenius equation below can be used to assess this temperature dependence:

$14 \quad k=A e^{\left(\frac{-E_{a}}{R T}\right)}$

where $\mathrm{k}$ is the reaction rate, $\mathrm{A}$ is the pre-exponential factor, $E_{a}$ is the activation energy $\left(\mathrm{kJ} \mathrm{mol}^{-1}\right), \mathrm{R}$ is the universal gas constant $\left(8.314 \mathrm{~kJ} \mathrm{~mol}^{-1} \mathrm{~K}^{-1}\right)$ and $\mathrm{T}$ the absolute temperature $(\mathrm{K})$. By assessing the reaction rate constant at two or more different temperatures, a non-linear regression (exponential) can be used to predict the rate of the reaction $(k)$ at a lower temperature (Van Boekel, 2008). For UC salads, using k of a first order degradation kinetic, the $E_{a}$ obtained was 63.01 $\mathrm{kJ} \mathrm{mol}^{-1}$. This value is in line with others reported in different food systems for AA degradation

21 (Villota and Hawkes, 2006, Timoumi et al., 2007). AA degradation modelling can be used as

22 additional nutritional information to consider when evaluating the shelf life of this RTE product 23 during different storage conditions. 
2 Total starch and in vitro digestion of starch. Predicted glycemic index

3 Total starch values for both types of salads were lower than those for the reference samples, white

4 bread and the cooked pasta alone (Table 6). The changes in the processing of the red bell pepper

5 did not significantly alter the total starch content of the salads. In the literature there is no total

6 starch content reported exclusively for pasta salads, so there are no means to compare the values

7 found. However, the values observed for the reference samples are similar to the ones reported by

8 other authors (Bustos et al., 2011, Rodríguez De Marco et al., 2014). It is established that the

9 cooking process of pasta produces the gelatinization of the starch, amylopectine crystals

10 disintegrate and the starch granules get swollen and ruptured. After cooling down, starch

11 retrogradation occurs where amylose and amylopectine aggregation and crystallization are

12 influenced by temperature and storage time, retrograded amylose from wheat was found to be

13 highly resistant to enzymatic degradation processes (Singh et al., 2010). Rapidly digestible starch

14 (RDS) was calculated after 30 min of digestion for both types of salads at the different storage temperatures as indicated by Rosin et al. (2002). During storage, the RDS content changed for both type of salads partly due to the retrogradation process during cold storage (Table 5). The RTE salads with cooked red bell pepper ( $C$ salads) followed first an increase (day 4 ) and a slight decrease (day 12) of their RDS content when stored at $4{ }^{\circ} \mathrm{C}$. However, when abuse temperature was used $\left(12{ }^{\circ} \mathrm{C}\right)$, the RDS content was maintained during the first days of storage and a slight increase was observed at the $12^{\text {th }}$ day (the lower the temperature the more changes in the RDS content). In the case of the

21 UC salads a decline of RDS content during storage is observed. As opposing to the C salads, the lowest quantity of RDS was found when the salads were stored at $12{ }^{\circ} \mathrm{C}$. These differences can be partially explained by changes and interactions during processing and storage with the other food components of the salads affecting the enzymatic digestibility of starch. Changes in RDS content 
and a decrease of available starch content during cold storage have been reported in different

2 foods (Sayago-Ayerdi et al., 2005, Rosin et al., 2002, Mishra et al., 2008).

3 Hydrolysis Index (HI) experimental values for white bread, cooked pasta and both type of salads

4 right after preparation were adjusted and the parameters of the first order reaction were

5 calculated (Table 6). The hydrolysis at $90 \mathrm{~min}$ is important because at this time the curves change and tend more slowly to a maximal plateau level. Experimental percentages of starch hydrolysis at this point are very similar to the ones obtained from the first order kinetic equation (Table 6), and the coefficient of determination is high $\left(R^{2}>0.98\right)$, both indicative of a very good fit. The reference

9 food (white bread), showed a starch hydrolysis percentage of $\sim 65 \%$ between the values observed by other authors (50-78\%) (Goñi et al., 1997, Rodríguez De Marco et al., 2014, Rosin et al., 2002).

Both types of salads and the pasta alone presented lower percentage of hydrolysis when compared with the white bread reference, meaning that the starch digestion was slower for these samples. Regarding the two type of salads, we found a higher starch digestion percentage at 90 min in the salad with uncooked red bell pepper, even higher than the cooked pasta alone. The addition of uncooked red bell pepper is exerting an increase in the digestibility of the starch. The composition of the food matrix also affects the starch digestion significantly (Singh et al., 2010). Lipids are known for affecting the hydrolysis by starch-lipid complexation depending on the nature of the lipids and starches, nonetheless, competitive trend between amylose-lipid complexation and amylose retrogradation has been found (Marze, 2013). With regards to the salads, fatty acid levels were similar for both types and only the total fat content was significantly higher in the UC salads. It has been reported that an increase in the starch digestion is expected with lower lipid content after cooking and cooling down (Tufvesson et al., 2001, Eerlingen et al., 1994). Although not analyzed directly, the high content of reducing agents (such as vitamin C) in the fresh bell peppers may facilitate the access to the starch granule by preventing the formation of enzyme complexes (Choi 
et al., 2008). In general, the food matrix complexity and the interaction among the components

2 after homogenization will most probably modify the integrity of the starch-protein network, known

3 to control the starch digestibility (Rodríguez De Marco et al., 2014, Marze, 2013).

4 The effect of storage time and temperature in the hydrolysis was different depending on the type

5 of salad (Fig 1). In the $C$ salads, day 0 exerts the lowest starch hydrolysis curve while in the UC

6 salads the lowest was the curve of the last day of storage. The temperature did not influence the

7 digestion of the $C$ salads (very similar curves can be observed). In the UC salads, however, the

8 starch hydrolysis curves were significantly higher at $4{ }^{\circ} \mathrm{C}$ than at $12{ }^{\circ} \mathrm{C}$. This means that the storage

9 at abuse temperature negatively impacted the digestion rate in the UC salad. These differences are

10 hardly explainable by the structural state of the starch, nor by the macronutrient composition of

11 the salads. The complexity of the food matrix and the differences during cold storage, point to a

12 more complex interaction among micronutrients and starch structural changes (Rosin et al., 2002,

13 Mishra et al., 2008). In two typical Mexican foods, tacos and tortillas with beans, the HI was found

14 to decrease with storage time, due to the increase of resistant starch and certain molecular

15 associations in the food matrix (Tovar et al., 2003, Sayago-Ayerdi et al., 2005).

16 pGI was calculated for both types of salads every four days of storage at two different

17 temperatures: $4^{\circ} \mathrm{C}$ and $12{ }^{\circ} \mathrm{C}$ (Table 7). $\mathrm{pGl}$ in $\mathrm{C}$ salads followed a similar trend at both storage

18 temperatures; it increased after 4 days of storage and decrease at the end of the storage time.

19 However, pGI values for UC salads followed a different pattern during storage. They remained

20 stable for 4 or 8 days (at $12{ }^{\circ} \mathrm{C}$ and $4{ }^{\circ} \mathrm{C}$, respectively) and then dropped at day 12 . Foods are

21 classified as low, medium or high glycemic using the following GI ranges (based on the glucose

22 reference): low $\leq 55 ;$ medium = 56-69; and high $\geq 70$ (Brand-Miller and Foster-Powell, 1999). The

23 RTE pasta salads are considered high GI for most of the storage period, and only the UC salads can 
1 be rated as medium $\mathrm{Gl}$ at the end of storage. This is an important fact to consider regarding the

2 nutritional properties of this RTE foods that can have a glucose response even higher than the

3 starchy ingredient by itself. These findings must be interpreted with caution, however, since the

4 digestion procedure was performed in vitro and it is unclear if same effects will be observed in vivo.

$5 \quad$ A high and positive correlation was found between the $\mathrm{HI}$ and the RDS ( $r=0.841)$ and between pGI

6 and RDS ( $r=0.902)$ for all the samples evaluated. Therefore, the RDS content can be a shorter

7 alternative for the measure of the in vitro starch digestion and pGI. According to our experimental

8 results the estimation of the $p G I$ with the RDS would be: $p G I=37.88+0.490 \times$ RDS. An also

9 positive (but higher) correlation between HI and RDS was found by Rosin et al. (2002) in different

10 starchy foods during storage.

\section{CONCLUSION}

13 This study proves that nutritional properties of commercially available ready-to-eat pasta salads

14 may significantly differ during storage time, thus affecting the health implications of their

15 consumption. AA degradation can be used as additional nutritional information to consider when

16 evaluating the shelf life of this RTE product during different storage conditions. In addition, future

17 studies evaluating the glycemic index of carbohydrate-based complete meals are encouraged, as GI

18 has been established as an important parameter in the prevention and management of metabolic

19 diseases.

21 ACKNOWLEDGEMENTS 
1 The research leading to these results has received funding from the European Community's

2 Seventh Framework Programme FP7, Theme KBBE.2011.2.1-01, research project STARTEC:

3 "Decision Support Tools to ensure safe, tasty and nutritious Advanced Ready-to-eat foods for

$4 \quad$ healthy and vulnerable Consumers", grant agreement No. 289262.

5 We would like to thank Mark Linton and Kelly Westley from the Agri-Food and Biosciences Institute

6 (Belfast, UK) for their technical assistance during the preparation and packaging of the samples.

\section{REFERENCES}

8 AOAC International (1998). Official Methods of Analysis of AOAC International. 16th edition, 4th 9 revision. Vol II. Maryland, USA.

10 AHLGREN, M., GUSTAFSSON, I.-B. \& HALL, G. 2004. Attitudes and beliefs directed towards ready11 meal consumption. Food Serv Technol, 4, 159-169.

12 ANTOGNELLI, C. 1980. The manufacture and applications of pasta as a food and as a food 13 ingredient: a review. Int J Food Sci Technol, 15, 125-145.

14 AUgustin, L. S. A., KENDALL, C. W. C., JENKINS, D. J. A., WILLETT, W. C., ASTRUP, A., BARCLAY, A. 15 W., BJÖRCK, I., BRAND-MILLER, J. C., BRIGHENTI, F., BUYKEN, A. E., CERIELLO, A., LA VECCHIA, C., LIVESEY, G., LIU, S., RICCARDI, G., RIZKALLA, S. W., SIEVENPIPER, J. L., TRICHOPOULOU, A.,

17 WOLEVER, T. M. S., BAER-SINNOTT, S. \& POLI, A. 2015. Glycemic index, glycemic load and glycemic response: An International Scientific Consensus Summit from the International Carbohydrate

19 Quality Consortium (ICQC). Nutr Metabol Cardiov Dis, 25, 795-815.

BARBAGALLO, R. N., CHISARI, M. \& PATANÉ, C. 2012. Polyphenol oxidase, total phenolics and

21 ascorbic acid changes during storage of minimally processed 'California Wonder' and 'Quadrato d'Asti' sweet peppers. LWT - Food Sci Technol, 49, 192-196. 
BJÖRCK, I., GRANFELDT, Y., LILJEBERG, H., TOVAR, J. \& ASP, N. G. 1994. Food properties affecting

2 the digestion and absorption of carbohydrates. Am J Clin Nutr, 59, 699S-705S.

3 BOFFA, L.,BINELLO, A., BOSCARO, V., GALLICCHIO, M., AMISANO, G., FORNASERO, S. \& CRAVOTTO,

4 G. (2016). Commiphora myrrha (Nees) Engl. extracts: evaluation of antioxidant and antiproliferative

5 activity and their ability to reduce microbial growth on fresh-cut salad. Int J Food Sci \& Technol, 51:

$6 \quad 625-632$

7 BRAND-MILLER, J. \& FOSTER-POWELL, K. 1999. Diets with a Low Glycemic Index: From Theory to

8 Practice. Nutr Today, 34, 64-72.

9 BUSTOS, M. C., PEREZ, G. T. \& LEÓN, A. E. 2011. Sensory and nutritional attributes of fibre-enriched pasta. LWT-Food Sci Technol, 44, 1429-1434.

11 CASTRO, S. M., SARAIVA, J. A., LOPES-DA-SILVA, J. A., DELGADILLO, I., LOEY, A. V., SMOUT, C. \& HENDRICKX, M. 2008. Effect of thermal blanching and of high pressure treatments on sweet green and red bell pepper fruits (Capsicum annuum L.). Food Chem, 107, 1436-1449.

14 CHOI, S. J., WOO, H. D., KO, S. H. \& MOON, T. W. 2008. Confocal Laser Scanning Microscopy to Investigate the Effect of Cooking and Sodium Bisulfite on In Vitro Digestibility of Waxy Sorghum 16 Flour. Cereal Chem J, 85, 65-69.

CHRISTIE, W. W. \& HAN, X. 2012. Isolation, Separation, Identification and Lipidomic Analysis,

18 Swaston, Woodhead Publishing.

CRUZ, R. M. S., VIEIRA, M. C. \& SILVA, C. L. M. 2008. Effect of heat and thermosonication treatments on watercress (Nasturtium officinale) vitamin C degradation kinetics. Innovative Food Sci Emerg Technol, 9, 483-488. 
1 FAJARDO-MARTÍN, V. A.-A., E.; VARELA-MOREIRAS, G 2013. Cuantificación de folato total en

2 alimentos ready-to-eat. Nutr Hosp, 28, 1210-1218.

3 FOLCH, J., LEES, M. \& SLOANE STANLEY, G. H. 1957. A simple method for the isolation and

4 purification of total lipides from animal tissues. J Biol Chem, 226, 497-509.

5 FOOD STANDARD AGENCY. (FSA). McCance \& Widdowson's Composition of Foods Integrated

Dataset, CoF IDS. Accessed on 10th November 2014. Available at:

7 http://tna.europarchive.org/20110116113217/http://www.food.gov.uk/science/dietarysurveys/diet

8 surveys/[Online].

9 GONÇALVES, C., RODRIGUEZ-JASSO, R. M., GOMES, N., TEIXEIRA, J. A. \& BELO, I. 2010. Adaptation

10 of dinitrosalicylic acid method to microtiter plates. Anal Method, 2, 2046.

11 GOÑI, I., GARCIA-ALONSO, A. \& SAURA-CALIXTO, F. 1997. A starch hydrolysis procedure to estimate

12 glycemic index. Nutr Res, 17, 427-437.

13 GRANFELDT, Y., BJORCK, I., DREWS, A. \& TOVAR, J. 1992. An in vitro procedure based on chewing to 14 predict metabolic response to starch in cereal and legume products. Eur J Clin Nutr, 46, 649-60. HOWARD, L. R. \& HERNANDEZ-BRENES, C. 1998. Antioxidant content and market quality of jalapeno pepper rings as affected by minimal processing and modified atmosphere packaging. J Food Qual,

$17 \quad 21,317-327$.

18 JENKINS, D. J., WOLEVER, T. M., TAYLOR, R. H., BARKER, H., FIELDEN, H., BALDWIN, J. M., BOWLING, 19 A. C., NEWMAN, H. C., JENKINS, A. L. \& GOFF, D. V. 1981. Glycemic index of foods: a physiological 20 basis for carbohydrate exchange. Am J Clin Nutr, 34, 362-6.

21 KAMEI, M., KI, M., KAWAGOSHI, M. \& KAWAI, N. 2002. Nutritional Evaluation of Japanese Take-out

22 Lunches Compared with Western-style Fast Foods Supplied in Japan. J Food Comp Anal, 15, 35-45.

23 LABUZA, T. P. 1984. Application of chemical kinetics to deterioration of foods. J Chem Edu, 61. 

LEE, S. K. \& KADER, A. A. 2000. Preharvest and postharvest factors influencing vitamin C content of

2 horticultural crops. Postharvest Biol Technol, 20, 207-220.

3 LIU, C., MA, T., HU, W., TIAN, M. AND SUN, L. (2016). Effects of aqueous ozone treatments on

4 microbial load reduction and shelf life extension of fresh-cut apple. I Int J Food Sci \& Technol, 51:

$5 \quad 1099-1109$.

MARZE, S. 2013. Bioaccessibility of nutrients and micronutrients from dispersed food systems:

7 impact of the multiscale bulk and interfacial structures. Crit Rev Food Sci Nutr, 53, 76-108.

MÉNDEZ, A. I. \& FALQUÉ, E. 2007. Effect of storage time and container type on the quality of extra-

9 virgin olive oil. Food Control, 18, 521-529.

MISHRA, S., MONRO, J. \& HEDDERLEY, D. 2008. Effect of Processing on Slowly Digestible Starch and

11 Resistant Starch in Potato. Starch, 60, 500-507.

12 MORELLÓ, J.-R., MOTILVA, M. A.-J., TOVAR, M. A.-J. \& ROMERO, M. A.-P. 2004. Changes in

13 commercial virgin olive oil (cv Arbequina) during storage, with special emphasis on the phenolic

14 fraction. Food Chem, 85, 357-364.

NAYAK, B., DE J. BERRIOS, J. \& TANG, J. 2014. Impact of food processing on the glycemic index (GI)

16 of potato products. Food Res Int, 56, 35-46.

17 OTENG-GYANG, K. \& MBACHU, J. I. 1987. Changes in the ascorbic acid content of some tropical

18 leafy vegetables during traditional cooking and local processing. Food Chem, 23, 9-17.

19 ÖZKAN, M., KIRCA, A. \& CEMEROǦLU, B. 2004. Effects of hydrogen peroxide on the stability of 20 ascorbic acid during storage in various fruit juices. Food Chem, 88, 591-597.

21 POlYDERA, A. C., STOFOROS, N. G. \& TAOUKIS, P. S. 2003. Comparative shelf life study and vitamin

22 C loss kinetics in pasteurised and high pressure processed reconstituted orange juice. J Food Eng, $2360,21-29$. 

RIZKALLA, S. W. 2014. Glycemic index: is it a predictor of metabolic and vascular disorders? Curr Opin Clin Nutr Metab Care, 17, 373-8. RODRÍGUEZ DE MARCO, E., STEFFOLANI, M. E., MARTíNEZ, C. S. \& LEÓN, A. E. 2014. Effects of spirulina biomass on the technological and nutritional quality of bread wheat pasta. LWT-Food Sci

5 Technol, 58, 102-108. ROSIN, P. M., LAJOLO, F. M. \& MENEZES, E. W. 2002. Measurement and Characterization of Dietary Starches. J Food Composition Anal, 15, 367-377. RUFIÁN-HENARES, J. Á., GUERRA-HERNÁNDEZ, E. \& GARCÍA-VILLANOVA, B. 2013. Effect of red sweet pepper dehydration conditions on Maillard reaction, ascorbic acid and antioxidant activity. J Food Eng, 118, 150-156.

SAYAGO-AYERDI, S. G., TOVAR, J., OSORIO-DIAZ, P., PAREDES-LOPEZ, O. \& BELLO-PEREZ, L. A. 2005. bean mixture: effect of cold storage. J Agric Food Chem, 53, 1281-5. Technol, 21, 168-180.

STRATAKOS, A. C.\& KOIDIS, A. (2015). Suitability, efficiency and microbiological safety of novel physical technologies for the processing of ready-to-eat meals, meats and pumpable products. Int J Food Sci Technol, 50: 1283-1302.

TARRAGO-TRANI, M. T., PHILLIPS, K. M. \& COTTY, M. 2012. Matrix-specific method validation for quantitative analysis of vitamin C in diverse foods. J Food Compos Anal, 26, 12-25. THOMAS, D. E., ELLIOTT, E. J. \& BAUR, L. 2007. Low glycaemic index or low glycaemic load diets for overweight and obesity. The Cochrane database of systematic reviews, CD005105. losses during infra-red drying of apple slices. LWT - Food Sci Technol, 40, 1648-1654. 
TONELLI, D., GATTAVECCHIA, E. \& BUDINI, R. 1981. Biochemical changes in green sweet peppers during storage at different temperatures. Food Chem, 7, 189-193. TOVAR, J., SÁYAGO-AYERDI, S. G., PEÑALVER, C., PAREDES-LÓPEZ, O. \& BELLO-PÉREZ, L. A. 2003. In Vitro Starch Hydrolysis Index and Predicted Glycemic Index of Corn Tortilla, Black Beans (Phaseolus vulgaris L.), and Mexican "taco". Cereal Chem J, 80, 533-535. TUFVESSON, F., SKRABANJA, V., BJÖRCK, I., ELMSTÅHL, H. L. \& ELIASSON, A.-C. 2001. Digestibility of

7 Starch Systems Containing Amylose-Glycerol monopalmitin Complexes. LWT-Food Sci Technol, 34, 131-139.

9 UDDIN, M. S., HAWLADER, M. N. A., DING, L. \& MUJUMDAR, A. S. 2002. Degradation of ascorbic 10 acid in dried guava during storage. J Food Eng, 51, 21-26.

11 ULBRICHT, T. L. V. \& SOUTHGATE, D. A. T. 1991. Coronary heart disease: seven dietary factors. The $12 \quad$ Lancet, 338, 985-992. USDA. United States Department of Agriculture. Nutritional database. Accessed on 10th November 14 2014. Available at: http://ndb.nal.usda.gov/ndb/search/list [Online]. VAN BOEKEL, M. A. J. S. 2008. Kinetic Modeling of Food Quality: A Critical Review. Compr Rev Food 16 Sci Food Saf, 7, 144-158.

17 VILLOTA, R. \& HAWKES, J. G. 2006. Reaction Kinetics in Food Systems. Handbook of Food 18 Engineering, Second Edition. Boca Raton, Florida: CRC Press.

19 WURSCH, P. 1989. Starch in human nutrition. World Rev Nutr Diet, 60, 199-256.

20 ZHENG, H. \& LU, H. 2011. Use of kinetic, Weibull and PLSR models to predict the retention of 21 ascorbic acid, total phenols and antioxidant activity during storage of pasteurized pineapple juice.

22 LWT - Food Sci Technol, 44, 1273-1281.

23 ZHOU, X., CHUNG, H. J., KIM, J. Y. \& LIM, S. T. 2013. In vitro analyses of resistant starch in 24 retrograded waxy and normal corn starches. Int J Biol Macromol, 55, 113-7. 
1 TABLE 1. FORMULATION OF RTE PASTA SALADS

\begin{tabular}{lc}
\hline Ingredient & g per batch \\
\hline Pasta $^{a}$ & 475 \\
Cooked Chicken & 287.5 \\
Grated Mozzarella & 125 \\
Grated Gouda Cheese & 37.5 \\
Red Bell Pepper & \\
Salt & 187.5 \\
Pepper & 6.25 \\
Olive Oil & 0.625 \\
Lemon juice & 125 \\
\hline
\end{tabular}

2

$3 \quad$ Weight after cooking

$4 \quad{ }^{b}$ Weight after processing (either 'cutting + washing' or 'cutting + boiling')

5

6 
1 TABLE 2. FATTY ACID PROFILE (AS \% OF TOTAL FAT) OF RTE SALADS AFTER PREPARATION AND

2 AFTER 12 DAYS OF STORAGE AT $12^{\circ} \mathrm{C}(\mathrm{N}=4)^{a}$

\begin{tabular}{|c|c|c|}
\hline Fatty acid & Day 0 & Day 12 \\
\hline C6:0 & $0.17 \pm 0.16$ & $0.36 \pm 0.11$ \\
\hline C8:0** & $0.00 \pm 0.00$ & $0.28 \pm 0.06$ \\
\hline $\mathrm{C} 10: 0^{* *}$ & $0.43 \pm 0.03$ & $0.72 \pm 0.10$ \\
\hline C12:0 & $0.84 \pm 0.22$ & $0.93 \pm 0.25$ \\
\hline C14:0 & $3.13 \pm 0.22$ & $3.71 \pm 0.59$ \\
\hline C16:0 & $18.11 \pm 0.52$ & $18.81 \pm 0.79$ \\
\hline C16:1 & $0.71 \pm 0.24$ & $0.85 \pm 0.12$ \\
\hline C18:0 & $4.74 \pm 0.32$ & $4.94 \pm 0.58$ \\
\hline C18:1 n9* & $65.72 \pm 1.41$ & $63.02 \pm 1.35$ \\
\hline C18:2 n6* & $5.53 \pm 0.22$ & $4.71 \pm 0.43$ \\
\hline C20:0 & $0.07 \pm 0.12$ & $0.13 \pm 0.15$ \\
\hline C18:2 n3 & $0.32 \pm 0.28$ & $0.36 \pm 0.25$ \\
\hline Other & $0.92 \pm 0.34$ & $1.06 \pm 0.39$ \\
\hline$\Sigma$ SFA & $22.77 \pm 0.24$ & $24.93 \pm 1.68$ \\
\hline$\Sigma$ MUFA $^{*}$ & $66.64 \pm 1.01$ & $64.07 \pm 1.45$ \\
\hline$\Sigma$ PUFA & $5.85 \pm 0.46$ & $5.06 \pm 0.59$ \\
\hline $\mathrm{Al}$ & $0.43 \pm 0.00$ & $0.50 \pm 0.06$ \\
\hline $\mathrm{TI}$ & $0.70 \pm 0.01$ & $0.77 \pm 0.05$ \\
\hline
\end{tabular}

3

$4 \quad{ }^{a}$ Means \pm SD. $*$ significant differences $(p<0.05), * *$ significant differences $(p<0.01)$. 
1 TABLE 3. EFFECT OF TEMPERATURE ON ASCORBIC ACID RETENTION (\%) DURING STORAGE OF

2 READY TO EAT SALADS PACKED UNDER MAP CONDITIONS ${ }^{a}$

\begin{tabular}{ccccc}
\hline Storage & \multicolumn{3}{c}{$\mathrm{C}^{b}$} & \multicolumn{2}{c}{$\mathrm{UC}^{c}$} \\
\cline { 2 - 5 } (days) & $4{ }^{\circ} \mathrm{C}$ & $12{ }^{\circ} \mathrm{C}$ & $4{ }^{\circ} \mathrm{C}$ & $12{ }^{\circ} \mathrm{C}$ \\
\hline 0 & $100.00 \pm 5.77 \mathrm{aA}$ & $100.00 \pm 5.77 \mathrm{dA}$ & $100.00 \pm 12.14 \mathrm{bA}$ & $100.00 \pm 12.14 \mathrm{cA}$ \\
4 & $101.18 .27 \pm 9.84 \mathrm{aB}$ & $81.01 \pm 10.41 \mathrm{cA}$ & $91.77 \pm 9.21 \mathrm{aB}$ & $79.99 \pm 11.18 \mathrm{bA}$ \\
8 & $100.10 \pm 5.36 \mathrm{aB}$ & $71.07 \pm 6.17 \mathrm{bA}$ & $84.52 \pm 6.20 \mathrm{aA}$ & $78.11 \pm 9.07 \mathrm{abA}$ \\
12 & $97.22 \pm 6.05 \mathrm{aB}$ & $59.65 \pm 7.54 \mathrm{aA}$ & $86.78 \pm 8.07 \mathrm{aB}$ & $70.99 \pm 10.56 \mathrm{aA}$
\end{tabular}

3

4 a Mean \pm standard deviation. For each type of salad, different uppercase letters within the same

5 storage time denote statistically significant differences $(p<0.05)$. Different lowercase letters in the

6 same column indicate significant differences $(p<0.05)$

$7 \quad{ }^{b} \mathrm{C}$ : salads with boiled red bell pepper, ${ }^{\mathrm{C}} \mathrm{UC}$ : salads with uncooked red bell pepper

8 
1 TABLE 4. REACTION RATE CONSTANTS AND COEFFICIENT OF DETERMINATION FOR ASCORBIC ACID

2 RETENTION OF RTE SALADS DURING STORAGE AT $4{ }^{\circ} \mathrm{C}$ AND $12{ }^{\circ} \mathrm{C}$

\begin{tabular}{lcccccc}
\hline \multirow{2}{*}{ SALAD } & Temperature & \multicolumn{2}{c}{ Zero order } & & \multicolumn{2}{c}{ First order } \\
\cline { 3 - 4 } \cline { 6 - 7 } & $\left({ }^{\circ} \mathrm{C}\right)$ & $\mathrm{k}\left(\% \mathrm{AA}_{\mathrm{R}}{ }^{-1} \mathrm{day}^{-1}\right)$ & $\mathrm{R}^{2}$ & & $\mathrm{k}\left(\right.$ day $\left.^{-1}\right)$ & $\mathrm{R}^{2}$ \\
\hline $\mathrm{C}^{a}$ & 12 & 3.330 & 0.796 & & 0.043 & 0.785 \\
$\mathrm{UC}^{b}$ & 4 & 1.206 & 0.252 & & 0.013 & 0.259 \\
& 12 & 2.373 & 0.484 & & 0.028 & 0.487 \\
& & & & & & \\
\hline
\end{tabular}

3

$4 \quad{ }^{a} \mathrm{C}$ : salads with boiled red bell pepper, ${ }^{b}$ UC: salads with uncooked red bell pepper 
1 TABLE 5. TOTAL STARCH (TS), RAPIDLY DIGESTIBLE STARCH (RDS) OF SALADS AND REFERENCE

$2 \operatorname{FOODS}^{a}$

\begin{tabular}{|c|c|c|c|c|}
\hline \multirow[t]{2}{*}{ Sample } & \multirow{2}{*}{$\begin{array}{c}\text { TS } \\
\text { (\%DM) }\end{array}$} & \multirow{2}{*}{$\begin{array}{l}\text { Storage } \\
\text { (days) }\end{array}$} & \multicolumn{2}{|c|}{ RDS (\%DM) } \\
\hline & & & $4^{\circ} \mathrm{C}$ & $12^{\circ} \mathrm{C}$ \\
\hline \multirow[t]{4}{*}{ C } & $36.02 \pm 3.28 a$ & 0 & $12.18 \pm 0.12 b A$ & $12.18 \pm 0.12 \mathrm{abA}$ \\
\hline & & 4 & $17.39 \pm 1.16 \mathrm{~dB}$ & $12.81 \pm 0.90 \mathrm{bA}$ \\
\hline & & 8 & $16.10 \pm 0.65 c B$ & $11.67 \pm 0.76 \mathrm{aA}$ \\
\hline & & 12 & $10.94 \pm 1.26 \mathrm{aA}$ & $15.62 \pm 0.54 c B$ \\
\hline \multirow[t]{4}{*}{ UC } & $35.72 \pm 3.15 a$ & 0 & $16.86 \pm 1.04 \mathrm{cA}$ & $16.86 \pm 1.04 \mathrm{cA}$ \\
\hline & & 4 & $14.74 \pm 1.15 b A$ & $16.10 \pm 1.34 \mathrm{cB}$ \\
\hline & & 8 & $15.73 \pm 0.49 b c B$ & $9.29 \pm 0.52 b A$ \\
\hline & & 12 & $10.04 \pm 0.65 a B$ & $7.86 \pm 1.15 a A$ \\
\hline Bread & $75.63 \pm 1.16 c$ & & $\mathrm{n} / \mathrm{a}$ & $\mathrm{n} / \mathrm{a}$ \\
\hline Pasta & $65.01 \pm 1.82 b$ & & $\mathrm{n} / \mathrm{a}$ & $\mathrm{n} / \mathrm{a}$ \\
\hline
\end{tabular}

3

$4{ }^{a}$ Means \pm SD. For each type of salad, different uppercase letters within the same storage time

5 denote statistically significant differences $(p<0.05)$, and different lowercase letters in the same

6 column indicate significant differences $(p<0.05)$ 
1 TABLE 6. PERCENTAGE OF TOTAL STARCH HYDROLYZED AT 90 MIN (H90), EQUILIBRIUM

2 CONCENTRATION $\left(\mathrm{C}_{\infty}\right)$, KINETIC CONSTANT (K), HYDROLYSIS INDEX (HI) FOR WHITE BREAD, PASTA

3 AND BOTH RTE SALADS ${ }^{a}$

\begin{tabular}{lccccc}
\hline & H90 exp & H90 th & $\mathrm{C}_{\infty}$ & $\mathrm{k}$ & $\mathrm{HI}$ \\
\hline White Bread & $61.92 \pm 2.12 \mathrm{c}$ & 62.43 & 65.82 & 0.033 & 100 \\
Pasta(Fusilli) & $44.53 \pm 1.10 \mathrm{a}$ & 46.56 & 47.07 & 0.050 & $75.86 \pm 3.01 \mathrm{a}$ \\
C Salad & $43.58 \pm 1.18 \mathrm{a}$ & 45.51 & 46.98 & 0.038 & $73.30 \pm 0.49 \mathrm{a}$ \\
UC Salad & $53.32 \pm 2.47 \mathrm{~b}$ & 57.03 & 57.68 & 0.050 & $92.90 \pm 2.18 \mathrm{~b}$ \\
& & & & & \\
\hline
\end{tabular}

$5 \quad{ }^{a}$ Means $\pm S D$. In the same column different letter denotes statistically significant difference $(p<0.05)$

6

7

8

9

10

11

12 
1 TABLE 7. PREDICTED GLYCEMIC INDEX FOR BOTH SALADS DURING STORAGE ${ }^{a}$

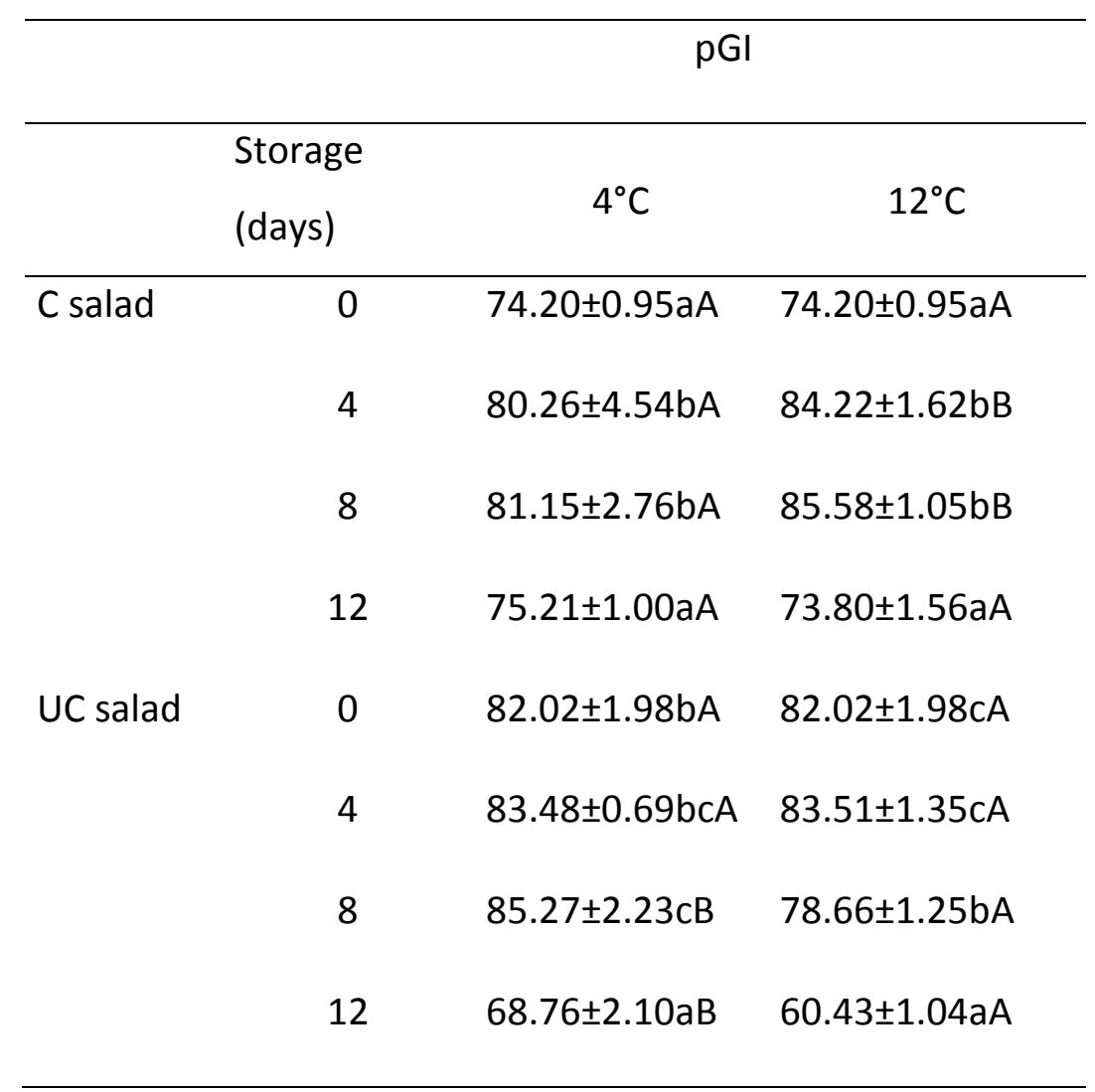

2

$3{ }^{a}$ Means \pm SD. For each type of salad, different uppercase letters within the same storage time

4 denote statistically significant differences $(p<0.05)$, and different lowercase letters in the same 5 column indicate significant differences $(p<0.05)$ 
FIG 1.

IN VITRO DIGESTION OF RTE PASTA SALADS. FIG. A AND B CORRESPONDS TO C SALADS STORED AT $4{ }^{\circ} \mathrm{C}$ AND $12{ }^{\circ} \mathrm{C}$, RESPECTIVELY. FIGURES C AND D CORRESPONDS TO UC SALADS STORED AT $4{ }^{\circ} \mathrm{C}$

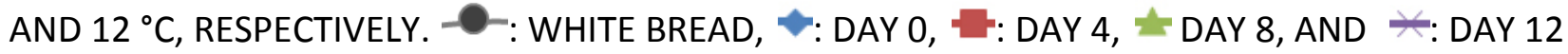

A

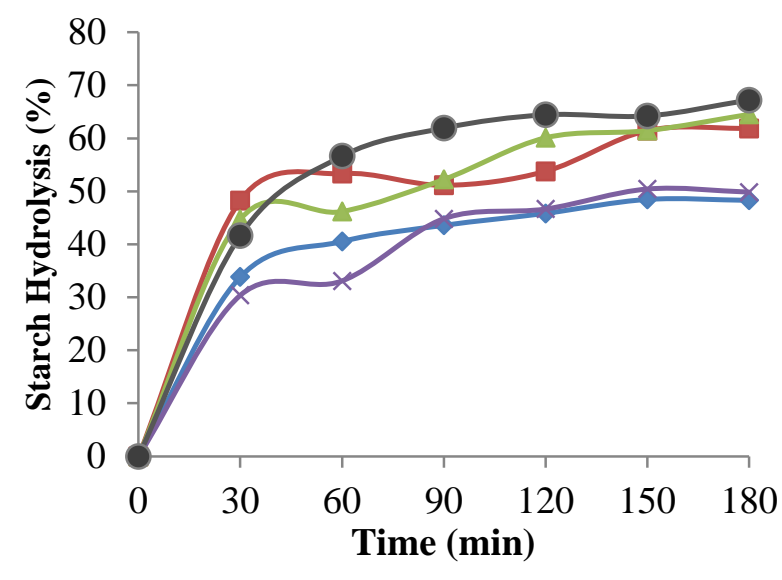

C

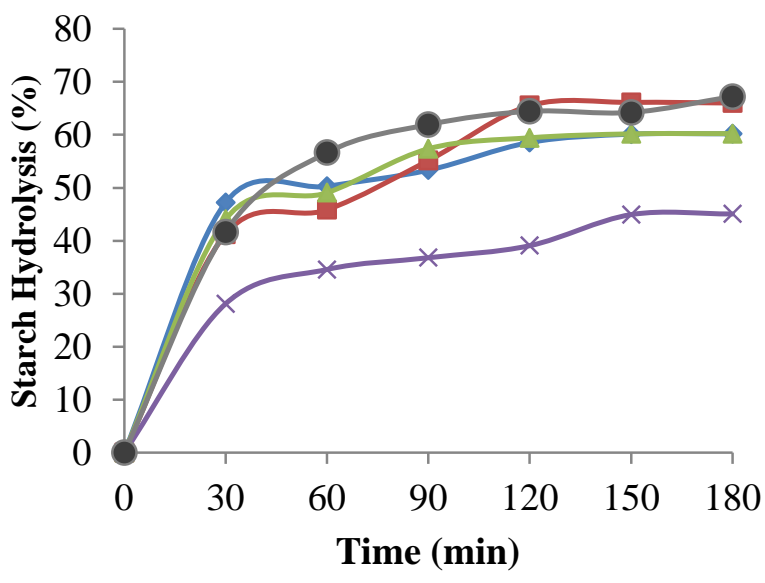

B

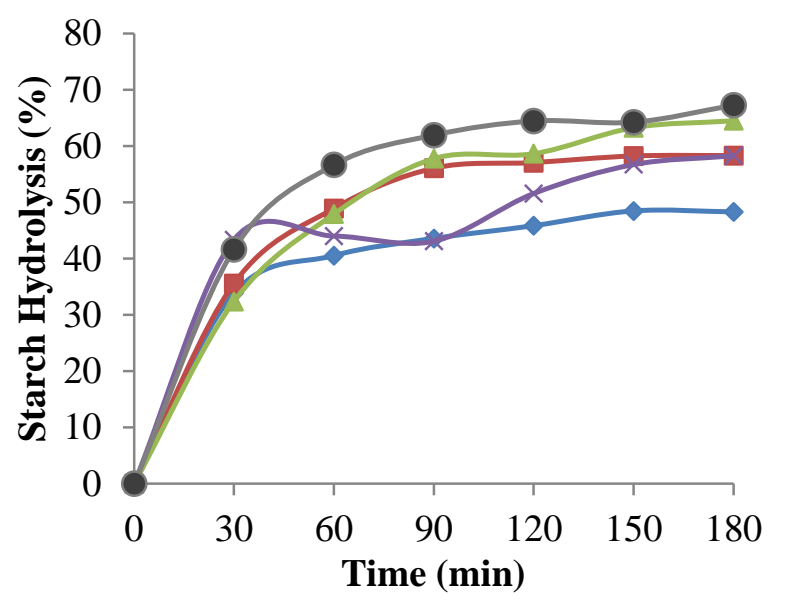

D

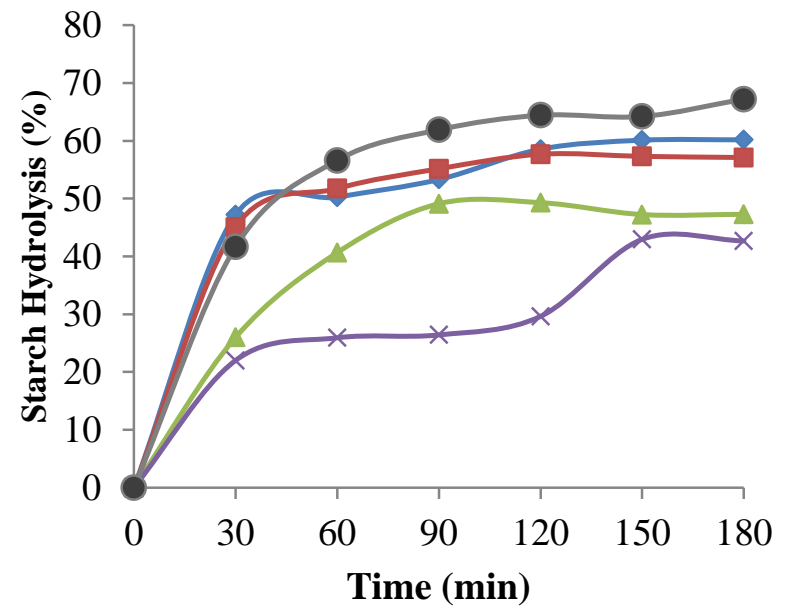

